\title{
A Mathematical Model for Prediction of Long-Term Degradation Effects in Solid Oxide Fuel Cells
}

\author{
Mina Naeini ${ }^{1}$, Haoxiang Lai ${ }^{1}$, James S. Cotton ${ }^{2}$, Thomas A. Adams II ${ }^{1 *}$ \\ ${ }^{1}$ Department of Chemical Engineering, McMaster University \\ ${ }^{2}$ Department of Mechanical Engineering, McMaster University \\ McMaster University, Hamilton, ON, L8S 4L7, Canada; naeinim@mcmaster.ca; \\ laih@mcmaster.ca; $\underline{\text { cottonjs@ mcmaster.ca }}$ \\ * Corresponding author: tadams@ mcmaster.ca
}

\section{Supporting Information}

\section{Validation}

As it was discussed in this paper, more than one model is presented for some of the system degradation mechanisms in the literature. The models for each degradation phenomena were validated against third-party experimental data (that were not used in developing those models) in order to select the best model. As an example, Fig. S1 a and b illustrate validation of the models that showed the best agreement with experimental data for anode electrical conductivity degradation and site percolation probability. 


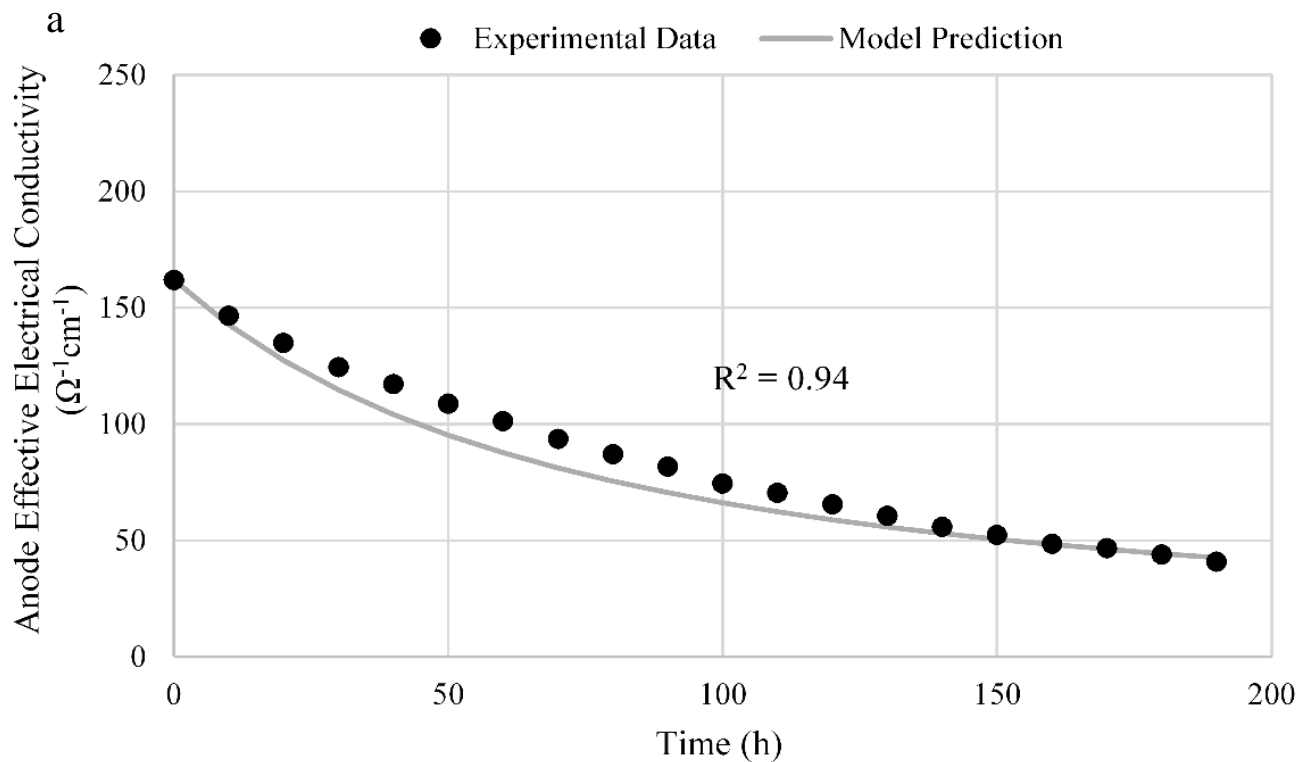

b

- Experimental Data Model Prediction

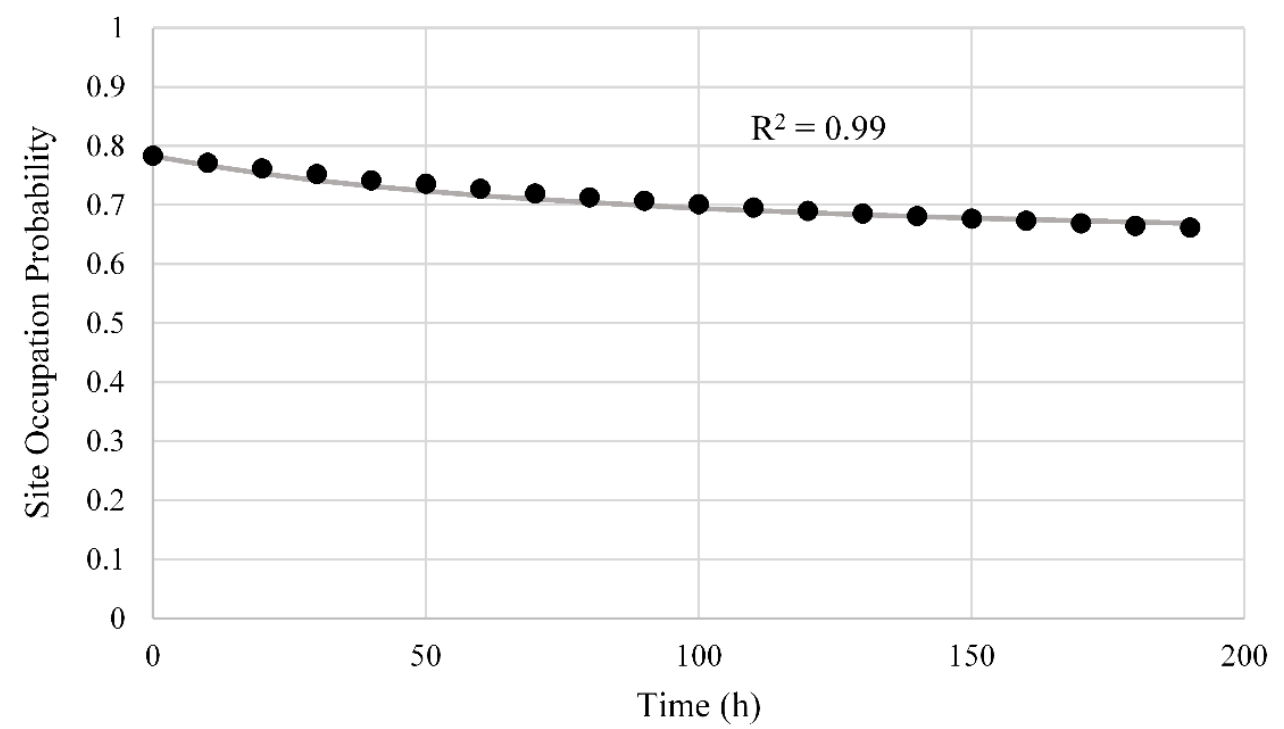

Fig.S1. Validating results of prediction model for: a) anode electrical conductivity against Klemenso et al's data $^{1}$, b) site occupation probability against Klemenso et al's data ${ }^{1}$.

The model was first validated for an $\mathrm{H}_{2} \mathrm{~S}$ containing fuel against a set of experimental data reported by Papurello et al. ${ }^{2}$, which was not used in the development of the model. This data was obtained using a cell running at $0.32 \mathrm{~A} / \mathrm{cm}^{2}$ with pre-reformed biogas and considered a range of $\mathrm{H}_{2} \mathrm{~S}$ concentrations contaminating hydrogen feed. A feed composition with $70.6 \%$ vol. $\mathrm{H}_{2}, 11.8 \%$ vol. $\mathrm{CO}_{2}, 17.6 \%$ vol. $\mathrm{CH}_{4}$ was selected. This fuel composition simulates a biogas mixture composed of $50 \%$ biogas to be reformed internally within the cells and $50 \%$ pre-reformed biogas from an 
external steam reformer. The tested cell had a 465-555 $\mu \mathrm{m}$ anode, 5-10 $\mu \mathrm{m}$ electrolyte, with a 30$60 \mu \mathrm{m}$ cathode. The output was predicted with an $\mathrm{R}^{2}$ of 0.85 , which illustrates the prediction model's general applicability for different cells with pre-reformed fuels (Fig. S2). The largest error occurred at very low $\mathrm{H}_{2} \mathrm{~S}$ concentrations but then model only slightly overpredicted voltage drop at about $1.6 \mathrm{ppm} \mathrm{H}_{2} \mathrm{~S}$ concentration and higher.

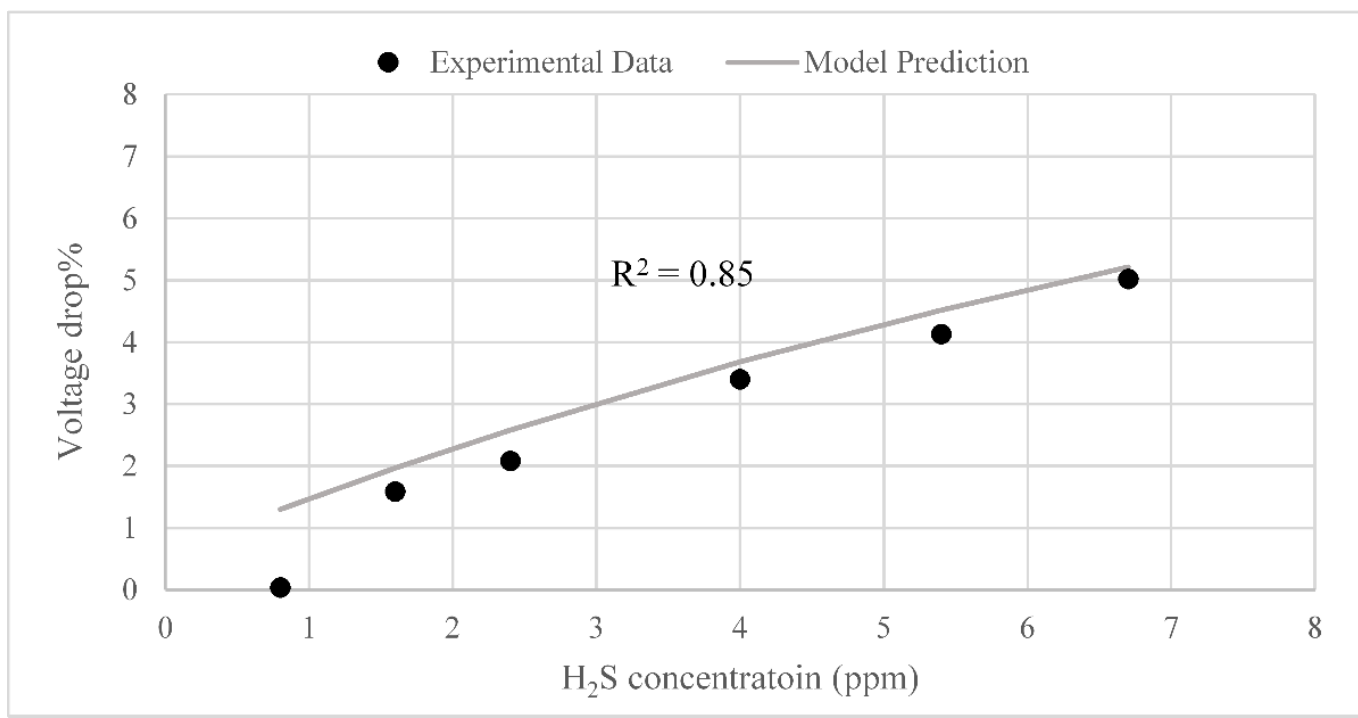

Fig. S2. Voltage drop percentage versus $\mathrm{H}_{2} \mathrm{~S}$ concentration at $0.32 \mathrm{~A} / \mathrm{cm}^{2}$. The line show results of the prediction model, while the circles represent Papurello et al.'s experimental data ${ }^{2}$.

This model was developed to predict the long-term performance of SOFCs under different operating conditions. As was noted in the modeling section, different models have been developed for each degradation mechanism. In order to find the best model for each process, their results were compared and validated using experimental data in the literature ${ }^{1,3-6}$, with those showing the best agreement with the data being selected for use in this study. Finally, using Hagen et al.'s experimental data (which was not considered in creating the model), we were able to validate the final results of the simulation over 1400 hours of operation for the fuel source without $\mathrm{H}_{2} \mathrm{~S}$ (Fig. $\mathrm{S} 3)^{7}$. The simulation results in Fig. S3 were obtained by running the degradation model with the same cell geometry and operating conditions $\left(0.75 \mathrm{~A} / \mathrm{cm}^{2}\right.$ and $\left.750^{\circ} \mathrm{C}\right)$ that were used in the experiments. As can be seen, the modeling results showed extremely good agreement with the experimental results over 1400 hours of operation, just slightly underpredicting the voltages achieved and otherwise following the trajectory very closely. 


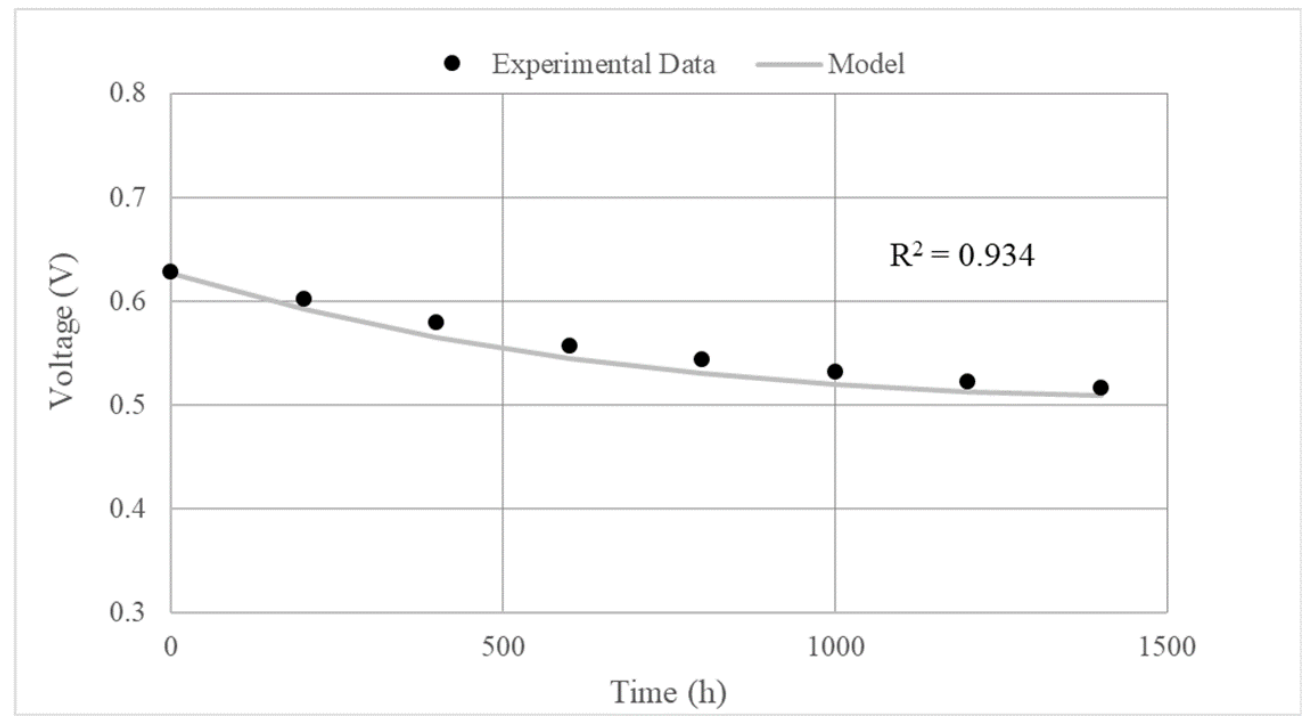

Fig. S3 Model results compared to experimental data from Hagen et al. ${ }^{7}$

Table S1. Input parameters used in the degradation model of SOFC.

$\begin{array}{llll}\text { Parameter } & \text { Value } & \text { Parameter } & \text { Value } \\ A & 100 \mathrm{~cm}^{2} & r_{\text {YSZ, }} & 1 \times 10^{-6} \mathrm{~m} \\ A_{0}^{V} & 4.55 \times 10^{8} \mathrm{~m}^{2} / \mathrm{m}^{3} & r_{\mathrm{Ni}, 0} & 1.02 \times 10^{-6} \mathrm{~m} \\ D_{w} & 14 \times 10^{-6} \mathrm{~m} & \overline{Z_{0}} & 6.7 \\ D_{s} & 6.35 \times 10^{-10} \mathrm{~m}^{2} \mathrm{~h}^{-1} & \varphi_{\mathrm{an}} & 0.4 \\ E_{\text {act,an }} & 10^{5} \mathrm{~J} \mathrm{~mol}^{-1} & \varphi_{\mathrm{ca}} & 0.5 \\ E_{\text {act,ca }} & 1.2 \times 10^{5} \mathrm{~J} \mathrm{~mol}^{-1} & \tau_{\mathrm{an}} & 9.5 \\ \mathrm{~F} & 96485 \mathrm{C} \mathrm{mol}^{-1} & \tau_{\mathrm{ca}} & 7.22 \\ \mathrm{k}_{\mathrm{B}} & 1.38 \times 10^{-23} \mathrm{~J} \mathrm{~K}^{-1} & \theta & 15^{\circ}\end{array}$




\begin{tabular}{|c|c|c|c|}
\hline$L_{\mathrm{an}}$ & $10^{-3} \mathrm{~m}$ & $\sigma_{\mathrm{ca}}$ & $8.0 \times 10^{4} \Omega^{-1} \mathrm{~m}^{-1}$ \\
\hline \multirow[t]{2}{*}{$L_{\mathrm{ca}}$} & $5 \times 10^{-5} \mathrm{~m}$ & $\sigma_{0, \text { an }}$ & $\left(3.27 \times 10^{4}-10.65\right.$ \\
\hline & & & T) $\times 10^{2} \Omega^{-1} \mathrm{~m}^{-1}$ \\
\hline$L_{\text {ele }}$ & $2 \times 10^{-5} \mathrm{~m}$ & $\sigma_{\text {ic }}$ & $1.5 \times 10^{6} \Omega^{-1} \mathrm{~m}^{-1}$ \\
\hline$L_{\mathrm{ic}}$ & $5 \times 10^{-4} \mathrm{~m}$ & $\varepsilon_{\mathrm{Ni}, 0}$ & 0.4 \\
\hline$L_{\mathrm{ac}}$ & $10^{-3} \mathrm{~m}$ & $\varepsilon_{\mathrm{YSZ}, 0}$ & 0.6 \\
\hline$L_{\mathrm{fc}}$ & $10^{-3} \mathrm{~m}$ & $v_{\mathrm{H}_{2}}$ & 6.12 \\
\hline$L_{\mathrm{t}}$ & $8 \times 10^{-3} \mathrm{~m}$ & $v_{\mathrm{H}_{2} \mathrm{O}}$ & 13.1 \\
\hline$L_{\mathrm{y}}$ & $0.1 \mathrm{~m}$ & $v_{\mathrm{O}_{2}}$ & 16.3 \\
\hline$L_{\mathrm{z}}$ & $0.1 \mathrm{~m}$ & $v_{\mathrm{N}_{2}}$ & 18.5 \\
\hline$L_{\text {an,opt }}$ & $3.75 \times 10^{-4} \mathrm{~m}$ & $\gamma_{\mathrm{an}}$ & $1.344 \times 10^{10} \mathrm{~A} \mathrm{~m}^{-2}$ \\
\hline$L_{\mathrm{ca}, \mathrm{opt}}$ & $7.2 \times 10^{-4} \mathrm{~m}$ & $\gamma_{\mathrm{ca}}$ & $2.051 \times 10^{9} \mathrm{~A} \mathrm{~m}^{-2}$ \\
\hline$n_{\mathrm{ch}}$ & 10 & $\gamma$ & $1.9 \mathrm{~J} \mathrm{~m}^{-2}$ \\
\hline$P_{\mathrm{f}}$ & $0.1 \mathrm{Mpa}$ & $\Omega$ & $1.09 \times 10^{-29} \mathrm{~m}^{3}$ \\
\hline$P_{\text {air }}$ & $0.1 \mathrm{Mpa}$ & $\delta_{s}$ & $2.5 \times 10^{-10} \mathrm{~m}$ \\
\hline$P_{\text {ref }}$ & $0.1 \mathrm{Mpa}$ & & \\
\hline $\mathrm{R}$ & $8.314 \mathrm{~J} \mathrm{~mol}^{-1} \mathrm{~K}^{-1}$ & & \\
\hline
\end{tabular}

\section{References}

(1) Klemens $\varnothing$, T.; Thydén, K.; Chen, M.; Wang, H. J. Stability of Ni-Yttria Stabilized Zirconia Anodes Based on Ni-Impregnation. J. Power Sources 2010, 195 (21), 7295-7301. https://doi.org/10.1016/j.jpowsour.2010.05.047.

(2) Papurello, D.; Lanzini, A.; Fiorilli, S.; Smeacetto, F.; Singh, R.; Santarelli, M. Sulfur Poisoning in Ni-Anode Solid Oxide Fuel Cells (SOFCs): Deactivation in Single Cells and a Stack. Chem. Eng. J. 2016, 283, 1224-1233. https://doi.org/10.1016/j.cej.2015.08.091.

(3) Hardjo, E.; Monder, D.; Karan, K. Numerical Modeling of Nickel-Impregnated Porous YSZ- 
Supported Anodes and Comparison to Conventional Composite Ni-YSZ Electrodes. ECS Trans. 2011, 35 (2 PART 2), 1823-1832. https://doi.org/10.1149/1.3570171.

(4) Faes, A.; Hessler-Wyser, A.; Presvytes, D.; Vayenas, C. G.; Vanherle, J. Nickel-Zirconia Anode Degradation and Triple Phase Boundary Quantification from Microstructural Analysis. Fuel Cells 2009, 9 (6), 841-851. https://doi.org/10.1002/fuce.200800147.

(5) Tanasini, P.; Cannarozzo, M.; Costamagna, P.; Faes, A.; Van Herle, J.; Hessler-Wyser, A.; Comninellis, C. Experimental and Theoretical Investigation of Degradation Mechanisms by Particle Coarsening in Sofc Electrodes. Fuel Cells 2009, 9 (5), 740-752. https://doi.org/10.1002/fuce.200800192.

(6) Zhu, W.; Ding, D.; Xia, C. Enhancement in Three-Phase Boundary of SOFC Electrodes by an Ion Impregnation Method: A Modeling Comparison. Electrochem. Solid-State Lett. 2008, 11 (6), 8386. https://doi.org/10.1149/1.2895009.

(7) Hagen, A.; Barfod, R.; Hendriksen, P. V.; Liu, Y. L.; Ramousse, S. Degradation of Anode Supported SOFCs as a Function of Temperature and Current Load. J. Electrochem. Soc. 2006, 153 (6), 1165-1171. https://doi.org/10.1149/1.2193400. 